\title{
EVALUASI PELAKSANAAN LAYANAN VOLUNTARY COUNSELING AND TESTING (VCT) DALAM PROGRAM PENCEGAHAN HIV/AIDS DI PUSKESMAS PAKUAN BARU KOTA JAMBI
}

\section{Evaluation on Implementation of Voluntary Counseling And Testing (VCT) Services in HIV/ AIDS Prevention Programs at Puskesmas Pakuan Baru Public Health Center, Jambi City}

\author{
Hubaybah $^{1}$, Evy Wisudariani ${ }^{1}$, Usi Lanita ${ }^{1}$ \\ ${ }^{1}$ Program Studi Ilmu Kesehatan Masyarakat Universitas Jambi
}

\begin{abstract}
Abstrak
Peningkatan kasus HIV/ AIDS ini diduga salah satunya disebabkan oleh ditutupnya kawasan lokalisasi Payo Sigadung. Pasca ditutupnya Payo Sigadung tahun 2014 lalu, tentunya menjadi salah satu "ancaman" dikarenakan sulitnya petugas kesehatan melakukan kontrol dan pengawasan terhadap pekerja seks komersial (PSK) tersebut. Hal ini dikarenakan kuat dugaan para pekerja seks komersial tersebut masih bekerja dengan sembunyi-sembunyi dan bahkan menyebar ke luar Payo Sigadung seperti di kawasan hiburan malam dan tempat-tempat lain seperti warung remang-remang dan tempat-tempat lainnya. Sehubungan dengan itu tentunya diperlukan inisiatif masyarakat yang memiliki kesadaran untuk melakukan pemeriksaan kesehatan secara berkala. Salah satu sarana yang bisa dimanfaatkan oleh masyarakat adalah layanan Voluntary Counseling and Testing (VCT) yang tersedia di Puskesmas. Penelitian ini bertujuan untuk melakukan Evaluasi Pelaksanaan Layanan VCT dalam Program Pencegahan HIV/AIDS di Puskesmas Pakuan Baru Kota Jambi. Studi Kualitatif dengan wawancara mendalam pada Maret-November 2020. Informan dalam penelitian ini yaitu konselor HIV/AIDS, petugas laboratorium/ farmasi, petugas administrasi dan pengunjung layanan VCT.Hasil penelitian yaitu Pelaksanaan layanan VCT, tingkat pengetahuan/ pemahaman informasi, sarana dan prasarana umumnya sudah cukup baik. Perlu adanya evaluasi berkala terhadap pelaksanaan layanan VCT, peningkatan ketrampilan petugas agar dapat menggali informasi lebih dalam dari pasien, perlu adanya peningkatan pengetahuan melalui pelatihan yang rutin.
\end{abstract}

Kata Kunci: HIV/AIDS, VCT, Puskesmas

\begin{abstract}
The increase number of HIV / AIDS cases suspected to be partly due to the closure of the Payo Sigadung (Prostitute Area). After the closure of Payo Sigadung in 2014, of course it became one of the "threats" due to the difficulty of health workers in controlling and supervising commercial sex workers (CSWs). This is due to the strong suspicion that these commercial sex workers are still working with strealthy and have even spread outside of Payo Sigadung such as in nightlife areas and other places such as dimly lit stalls and other places. So, it requires community initiative that has the awareness to carry out periodic health checks. One of the facilities that can be used by the community is the Voluntary Counseling and Testing (VCT) service available at the Puskesmas. This study aims to evaluate the implementation of VCT services in the HIV / AIDS Prevention Program at the Pakuan Baru Community Health Center, Kota Jambi. Qualitative study with in-depth interviews from March-November 2020. The informants in this study were HIV / AIDS counselors, laboratory / pharmacy staff, administration officers and visitors to VCT services. The results of the study were the implementation of VCT services, level of knowledge / understanding of information, general facilities and infrastructure. is good enough. There is a need for periodic evaluation of the implementation of VCT services, increasing the skills of officers in order to dig deeper information from patients, there is a need for increased knowledge through routine training. Keywords: HIV / AIDS, VCT, Public Health Center
\end{abstract}

Korespondensi : Evy Wisudariani

Email: evywisudariani@unja.ac.id 


\section{PENDAHULUAN}

HIV/ AIDS merupakan penyakit menular yang jumlah pengidap terlapornya semakin meningkat dan pertama kali di Indonesia ditemukan di Provinsi Bali pada tahun 1987. Hingga saat ini HIV AIDS sudah menyebar di 386 Kabupaten/Kota di seluruh Provinsi di Indonesia. Di Kota Jambi, diketahui bahwa jumlah pengidap HIV selama Januari hingga September 2019 sebanyak 51 orang dengan proporsi HIV sebanyak 38 orang dan AIDS 13 orang (1).

Data dari Riset Kesehatan Dasar Indonesia Tahun 2018 menunjukkan bahwa sebanyak $65,2 \%$ penduduk Indonesia memiliki pengetahuan yang kurang mengenai HIV/AIDS, sementara di Provinsi Jambi sebanyak $55 \%$. Peningkatan jumlah kasus HIV/AIDS berbanding terbalik dengan semakin gencarnya usaha-usaha penanggulangan HIV/AIDS. Salah satu kemungkinan yang terjadi adalah dengan semakin gencar dan intensifnya kegiatan penanggulangan HIV/AIDS menyebabkan meningkatnya jumlah pengidap yang terdeteksi (2).

Penanggulangan HIV/AIDS dimulai dari tingkat pencegahan, pengobatan hingga support (dukungan). Hal ini sangat berkaitan erat dan pelaksanaannya dilakukan secara komprehensif. Dalam upaya pencegahan HIV yang efektif perlu memberikan edukasi agar masyarakat tahu upaya untuk mendeteksi dini. Perlunya pengetahuan mengenai faktor risiko, penjelasan tentang obat-

obat infeksioportunis dan obat-obat Anti retroviral (ARV) diperlukan pada saat konseling dan sebagainya. Sebaliknya pada saat melakukan pengobatan diperlukan dukungan untuk pengetahuan edukasi tentang pola hidup, perilaku pendampingan dalam menjalani pengobatan.

Voluntary Conseling and Testing (VCT) merupakan upaya pencegahan dan deteksi dini untuk mengetahui status seseorang sudah terinfeksi HIV atau belum yaitu melalui konseling dan testing HIV/AIDS sukarela. VCT salah satu kegiatan untuk mencegah maupun mengobatikarena VCT merupakan pintu masuk antara lain mencegah penularan dari ibu ke bayi (PMTCT), perubahan perilaku. Peran VCT sebagai fasilitas pengobatan antara lain membuka akses untuk pengobatan infeksi oportunistik, pengobatan ARV dan menghilangkan stigma dan diskriminasi serta pelanggaran hak azasi terhadap ODHA dan keluarganya.

Masih tingginya kasus HIV di Kota Jambi membuat cakupan pelayanan VCT semakin bertambah. Tidak hanya pada Rumah Sakit namun juga terdapat pada Pusat Pelayanan Kesehatan Dasar atau Puskesmas. Berdasarkan data dari Dinas Kesehatan Kota Jambi Tahun 2019, saat ini Puskesmas memiliki fasilitas layanan VCT salah satunya yaitu Puskesmas Pakuan Baru. Puskesmas sebagai pusat pelayanan kesehatan dasar memiliki tugas pokok salah satunya upaya pencegahan (preventif) dan promosi kesehatan (promotif) tentunya memiliki peranan besar dalam penanggulangan HIV/AIDS melalui layanan VCT secara aktif (3).

Tingginya kasus HIV/AIDS di Kota Jambi tentunya perlu mendapat perhatian serius mengingat sebagai penyakit menular berbahaya tentunya membutuhkan perhatian lebih dari setiap elemen dan stakeholder khususnya di Kota Jambi. Peningkatan kasus HIV/ AIDS ini diduga salah satunya disebabkan oleh ditutupnya kawasan lokalisasi Payo Sigadung. Pasca ditutupnya Payo Sigadung tahun 2014 lalu, 
tentunya menjadi salah satu "ancaman" dikarenakan sulitnya petugas kesehatan melakukan kontrol dan pengawasan terhadap pekerja seks komersial (PSK) tersebut. Hal ini dikarenakan kuat dugaan para pekerja seks komersial tersebut masih bekerja dengan sembunyi-sembunyi dan bahkan menyebar ke luar Payo Sigadung seperti di kawasan hiburan malam dan tempat-tempat lain seperti warung remangremang dan tempat-tempat lainnya.

Sehubungan dengan itu tentunya diperlukan inisiatif masyarakat yang memiliki kesadaran untuk melakukan pemeriksaan kesehatan secara berkala, terlepas dari apakah terhadap penderita HIV/ AIDS atau bukan mengingat semua orang berpotensi terjangkit virus HIV/ AIDS mengingat penyebab penularan HIV AIDS bukan hanya karena terjadi kontak seksual saja, termasuk penyebab-penyebab lainnya. Salah satu sarana yang bisa dimanfaatkan Oleh masyarakat adalah VCT yang tersedia di Puskesmas khususnya di Kota Jambi. Hanya saja sejauh ini kesadaran masyarakat untuk memanfaatkan sarana VCT itu masih sangat rendah, maka dalam hal ini tentunya diperlukan peningkatan kesadaran dan pemahaman masyarakat akan pentingnya pemeriksaan kesehatan berkala khususnya dalam hal ini pemanfaatan VCT tersebut. Untuk itu peneliti tertarik melakukan Evaluasi Pelaksanaan Layanan Voluntary Counseling And Testing (VCT) dalam Program Pencegahan HIV/AIDS di Puskesmas Pakuan Baru Kota Jambi .

\section{METODE}

Penelitian ini dilakukan menggunakan observasional dengan pendekatan deskriptif, menggunakan studi kualitatif yang dilaksanakan selama sekitar 8 (delapan) bulan sejak Maret 2020 sampai dengan November 2020 di Puskesmas Pakuan Baru. Informan penelitian ini adalah Konselor HIV/AIDS, petugas laboratorium/ farmasi, petugas administrasi dan pengunjung layanan VCT yang dilakukan dengan wawancara mendalam guna mengkonfirmasi data penelitian untuk membantu menggali akar permasalahan yang diidentifikasi terkait program pencegahahan HIV/AIDS dari segi pelaksanaan VCT dan sarana prasarana klinik VCT serta data sekunder dikumpulakn dari Puskesmas dan Dinas Kesehatan Kota Jambi.

\section{HASIL}

Berdasarkan wawancara mendalam yang dilakukan, menunjukkan bahwa petugas labolatorium klinik VCT Puskesmas telah melaksanakan tahapan testing HIV sesuai dengan standar, yaitu menggunakan Strategi III. Hasil wawancara kepada petugas laboratorium (LB2 dan LB3) sebagai berikut:

"Pertama kita ambil darah dulu sebanyak 3 cc, untuk tes itu ada tiga tahap yang pertama apabila hasilnya reaktif dilanjutkan ke pemeriksaan yang kedua, apabila hasil tes kedua reaktif juga di tes lagi yang ketiga jika tes kesatu,kedua, dan ketiga reaktif berarti memang HIV tapi kalau cuman satu belum."...(LB2)

"Kita terima dulu dari ibu xxxx (konselor ruang konseling) sudah di konseling baru bawa kesini sudah dibawa kesini baru pemeriksaan, pemeriksaan ini ada tiga tahap, tahap pertama reagen 1 kalau negarif hasilnya selesai kita serahkan lagi ke ibu Santi, kalau 
positif kita lanjut ke reagan 2 kalau reagan duanya negaif kitta ulang lagi tes reagen 1 di hari yang sama, nanti kalau misalkan reagen 2 nya positif baru lanjut reagen 3 kalau positif berarti hasilnya reaktif, kalau reagen 2 negatif berarti inklusif, besok itu diulang lagi 15 hari."...(LB3)

Berdasarkan hasil wawancara yang telah dilakukan dengan konselor dan petugas laboratorium diketahui bahwa alur/ SOP pelayanan VCT dari tahap awal hingga akhir sudah baik, sebagaimana seperti yang terlihat dari wawancara sebagai berikut:

"Alur disini ada dua macam yang pertama umum, untuk yang umum tahap pertama yaitu kedatangan pasien langsung ke loket, kemudian diarahkan ke poli dewasa, setelah itu ke poli IMS/HIV apabila terdapat keluhan misalnya kencing bernanah atau ada keluhan lain misal dia melakukan hubungan seks bebas, setelah diperiksa HIV nya, jika ia pasien bawaan LSM biasanya buka diluar jam kerja namanya extra time di jam 2-5 mereka langsung ke poli IMS/HIV tanpa ke loket dan tanpa bayaran. Setelah di poli IMS/HIV masuk ke ruang konseling untuk mengisi formulir, register setelah itu mereka ke labor, setelah itu pasien menunggu hasil dan kemudian masuk lagi keruang konseling. "...(KO1)

"Kan mereka dari registrasi nanti terus ke poli dewasa setelah itu ke ruang vct nah baru ke labor."...(LB3)
Namun demikian dari hasil wawancara tersebut ternyata masih ditemukan sebagian kecil konselor dan petugas laboratorium yang tidak menjelaskan alurnya, hal ini dapat terlihat seperti pada hasil wawancara sebagai berikut:

" oh untuk alur nya ya, nanti kita kasih.”... (KO2)

"Alurnya ado tu di papan luar."...(LB2)

Selain itu diketahui pula bahwa pada umumnya informan (pasien) masih kurang memahami tujuan dan manfaat VCT, hal ini dijelaskan dalam hasil wawancara berikut:

"dak tau dek, kami tes ini baru satu kali ini lah”...(IP4)

"dak tau kami vct tu apo, emang ini tes kedua kali tapi dak tau apo itu’...(IP6)

Namun hal ini, bertolak belakang dengan pernyataan konselor. Berdasarkan hasil wawancara diketahui bahawa konselor telah memberikan informasi yang jelas tentang HIV/AIDS kepada pasien. Berikut hasil wawancara:

" sebelum memberikan informasi kita tanya dulu kita tanya seputar formulir banyak juga yang kita tanya, karna banyak juga yang Belum mau terbuka bahwa mereka telah melakukan hubungan dengan sesama laki-laki, karna disini kebanyakan pasiennya adalah LSL, caranya kita untuk menggali informasi itu kita tanya pelanpelan lah kapan terakhir berhubungan, berhubungan dengan siapa saja kita tanya, 
emang ada sebagian mereka yang belum mau untuk terbuka terhadap laki-laki tapi ada juga yang langsung terbuka tergantung orangnya. Nah untuk informasi yang kita kasih itu berkaitan dengan formulir seperti faktor risiko, serta pengobatan jika hasil tes positif dan diarahkan lah seperti edukasi.',...(KO1)

" pasti kita tanya dulu kan, tujuan pemeriksaan nya apa, mungkin dia merasa kalau yang bawaan pendamping otomatis kan dia sudah mengetahui sebelumnya kenapa dia dibawa kesini, kalau dia ditangkap dari ruang periksa umum/ poli dewasa kita ini dulu kasih penjelasan "bapak tujuan saya untuk melakukan kita mengadakan cek virus, bapak tau virus, virus itu dia masuk kedalam tubuh, yang kita cek ini virus HIV namanya, bapak tau HIV, jadi bapak HIV itu virus bapak, virus yang masuk kedalam tubuh kita, dan masuk kedalam aliran darah bapak, kita sampaikan pakek bahasa kitalah supaya dia ngerti kan, sepahamnya dia, nanti pasti dia tanya kenapa saya cek virus bu, makanya kita konseling dulu jadi kita jelasin lah biasanya kalau ada tanda dan gejala seperti itu kita harus cek virus, cek virus nya gratis. ”...(KO3)

Berdasarkan wawancara diatas, konselor sudah memberikan penjelasan kepada pasien. Ketidaktahuan pasien akan apa itu VCT salah satunya disebabkan karena pasien masih belum terbuka atas pertanyaan yang diajukan oleh konselor.
Sehingga komunikasi dua arah tidak tercapai. Sementara pasien masih belum paham akan informasi seputar HIV dan VCT itu. Namun, pasien mengakui bahwa petugas sangat ramah dan sopan pada saat melakukan konseling.

"enak kok, ibu dalam ruangannya juga enak ngobrolnya enak, nyaman lah di dalam,"

Diketahui pula, bahwa konselor telah menggunakan bahasa yang mudah dimengerti oleh pasien, terutama hati-hati dalam memberikan penjelasan terhadap hasil test nya. Setelah hasil disampaiakan, barulah pasien mulai terbuka dan bisa diajak berkomunikasi, sehingga konselor terus memancing beberapa pertanyaan terhadap pasien. Berikut pernyataan dari konselor:

"terkadang memang agak susah gitu kan, biasanya saya ngomong seperti ini "bapak ini saya sebelumnya mungkin dari pertanyaan saya ke bapak agak privasi, mungkin agak pribadi sedikit, tapi informasi ini tidak untuk dipublikasikan bapak, jadi saya harapkan bapak jujur untuk menjawab, cuman nanya untuk data aja pak gitu, kita tanya lah bapak pernah ada kontak risiko dak kita terangin lah penularan HIV itu dari ini-ini, kalau dia positif kita ulangi lagi tadi penlaran HIV ada berapa tadi pak", nanti dia bakal jawab terus kita tanya di penularan tadi ada salah satunya tadi kan pak, nanti biasanya pasien nya pasti bakal cerita nah kalau sudah dia cerita kita sampaikan kalau hasilnya itu positif, setelah dengar itu memang 
biasanya pasein itu temenung, nah kita kasih penguat kita bilang sekarang gini pak bapak ngak usah takut, ngak usah bapak merasa gimana gitu kan, nah yang namanya penyakit nanti kita akan kasih obat atau terapinya, dengan catatan obat ini tidak untuk menyembuhkan nah jadi bapak minum obat ini adalah seumur hidup, obat ini tidak menyembuhkan virus dalam tubuh bapak, karena virus itu mengalir dalam aliran darah tubuh bapak, saya bilang seperti itu bapak minum obatnya semur hidup, nah obat ini fungsinya untuk menekan virus yang ada dalam tubuh bapak biar tidak mengerogoti sel-sel imun bapak, pokokny kita sampaikan pakai bahasa yang mereka paham lah yang mereka ngerti. Kalau yang negatif kita jelasin kayak gini bapak dari hasil pemeriksaan darah ini seperti yang sudah saya terangin tadi proses perjalanan virus HIV, nah untuk sementara ini hasilnya masih negatif, nah tapi 3 bulan lagi bapak harus kembali cek ulang lagi, jadi kita sarankan untuk cek ulang lagi ",

Selain itu, hasil observasi dan wawancara kepada pasien terkait dengan kenyamana ruangan VCT dan laboratorium menyatakan bahwa ruangan sudah cukup nyaman. Hasil pernyataan informan sebagai berikut:

" ruangannya enak, dak panas, bersih lah.”...(IP1)

Hasil observasi yang dilakukan menunjukkan bahwa ruangan sudah bersih, tersedia brosur dan leaflet terkait HIV, serta poster yang tertempel di dinding. Terdapat pula alur pelayanan VCT yang di tempel di dekat ruang tunggu pasien. Sementara laboratorium masih bergabung dengan laboratorium umum lainnya.

\section{PEMBAHASAN}

Karakteristik responden yang melakukan kunjungan pada layanan VCT di Puskesmas berdasarkan hasil penelitian menunjukkan bahwa sebagian besar responden berada pada usia produktif dengan tingkat pendidikan paling banyak pada tingkat pendidikan Sekolah Menengah Atas (SMA). Pendidikan yang dimiliki seseorang dapat mempengaruhi perilakunya, yang mana pada umumnya semakin tinggi pendidikan seseorang seharusnya semakin mudah untuk menerima informasi. Selain itu dari hasil penelitian juga diketahui bahwa tingkat pendidikan pada informan yang bertugas sebagai konselor maupun petugas laboratorium rata-rata mempunyai tingkat pendidikan Diploma III (D3). Berdasarkan hasil tersebut dapat disimpulkan bahwa tingkat pendidikan baik itu tingkat pendidikan pasien maupun petugas kesehatan mempunyai tingkat pendidikan yang tinggi.

Menurut Budiman (2013) pendidikan merupakan proses yang dilakukan untuk mengubah sikap dan tatatlaku seseorang melalui upaya pengajaran dan pelatihan. Seseorang yang memiliki pendidikan yang semakin tinggi akan mudah menerima dan menyesuaikan diri dengan hal-hal baru. Selain itu sebenarnya pendidikan merupakan salah satu faktor yang mempunyai hubungan dengan tingkat pengetahuan seseorang, walaupun memang peningkatan pengetahuan tidak mutlak diperoleh dari pendidikan yang 
formal, namun dapat juga diperoleh dari pendidikan non formal (4).

Sejalan dengan hasil penelitian yang dilakukan oleh Teklehaimanot, et.al (2016) dengan judul "Factors Influencing the Uptake of Voluntary HIV Counseling and Testing in Rural Ethiopia" menunjukkan hasil bahwa orang dengan pendidikan yang lebih baik akan lebih bersedia untuk datang melakukan pemeriksaan status HIV ke fasilitas layanan kesehatan. Sama halnya dengan penelitian yang dilakukan oleh Rosida (2018) yang melakukan penelitian berkaitan "Hubungan Pengetahuan Tentang HIV/AIDS dengan Pemanfaatan VCT di Puskesmas Gedongtengen Yogyakarta", hasil penelitian diketahui bahwa sebagian besar responden yang datang untuk memanfaatkan layanan VCT di Puskesmas mempunyai pendidikan yang tinggi. Berdasarkan uraian-uraian tersebut dapat dinyatakan bahwa semakin tinggi atau baik tingkat pendidikan seseorang maka akan membuat seseorang akan melakukan pemanfaatan layanan VCT di Puskesmas $(5,6)$.

Terkait pengetahuan responden yang melakukan kunjungan pada layanan VCT di Puskemas dari hasil penelitian diketahui bahwa sebagian besar responden mengetahui fungsi dari dilakukannya layanan VCT. Begitu juga dengan pengetahuan yang dimiliki oleh konselor maupun petugas laboratorium sudah cukup baik. Pengetahuan konselor dan petugas laboratorium ini terlihat bahwa mereka telah mengetahui SOP dalam memberikan layanan VCT di Puskesmas dan telah mendapatkan pelatihan terkait VCT HIV. Terdapat empat jenis konselor yang kompeten dalam memberikan layanan konseling berdasarkan model implementasi dan strategi untuk meningkatkan layanan VCT, yaitu konselor sebaya (peer counselor), konselor awam (lay counselor), konselor professional (professional counselor), dan konselor senior (senior counselor). Konseling merupakan proses membantu seseorang untuk belajar menyelesaikan masalah interpersonal, emosional dan memutuskan hal tertentu. Peran seorang konselor adalah membantu klien (7).

Menurut Notoatmodjo (2014) pengetahuan merupakan hasil dari tahu dan ini terjadi setelah orang melakukan pengindraan terhadap suatu objek tertentu. Dalam hal penelitian ini pengetahuan berkaitan dengan upaya program pencegahan HIV dengan memanfaatkan layanan VCT di Puskesmas yang ada di Kota Jambi. Seseorang yang mempunyai pengetahuan yang baik biasanya akan menyadari akan pentingnya kesehatan terutama untuk mencegah penularan atau terkena HIV. Begitu juga dalam hal pemanfaatan layanan VCT HIV, orang yang mempunyai pengetahuan yang baik akan lebih cenderung memanfaatakan layanan kesehatan tersebut untuk melakukan deteksi dini ataupun sebagai upaya pencegahan dan pengobatan segera mungkin terkait HIV (8).

Pengetahuan pasien maupun petugas kesehatan terkait layanan VCT di Puskesmas yang cukup baik ini sejalan dengan beberapa hasil penelitian yang telah dilakukan oleh peneliti lain. Penelitian yang dilakukan oleh Nurhayati (2016) yang menyatakan bahwa ada hubungan yang signifikan antara pengetahuan dengan keikutsertaan ibu dalam melakukan pemeriksaan VCT yang mana ibu yang mempunyai pengetahuan yang tinggi ternyata 5 kali lebih memanfaatkan pemeriksaan VCT dibandingkan dengan ibu yang mempunyai 
pendidikan rendah. Dengan demikian, dapat disimpulkan bahwa dalam program pencegahan HIV dapat dilakukan dengan meningkatkan pengetahuan masyarakat tentang HIV/AIDS sehingga diharapkan nanti masyarakat akan secara sadar pentingnya untuk melakukan pemeriksaan VCT HIV baik itu di Puskesmas maupun di fasilitas pelayanan kesehatan lainnya (9).

Sarana dan prasarana yang ada di Puskesmas sudah baik. Hal ini diketahui dari hasil penelitian yang mana menunjukkan bahwa tersedianya sarana dan prasarana dalam layanan VCT diantaranya ada ruangan khusus untuk melakukan konseling, adanya laboratorium untuk melakukan pemeriksaan darah, adanya brosur, leaflet, poster tentang HIV/AIDS dan semua pasien menyatakan bahwa kondisi ruangan yang nyaman, dingin serta bersih. Kenyamanan adalah penerimaan pasien terhadap kondisi/keadaan yang dilihat dan dirasakan langsung untuk pasien yang menerima pelayanan VCT. Sarana dan prasarana akan sangat berpengaruh dalam proses pelayanan karena VCT merupakan pelayanan yang mengutamakan kenyaman dan privasi pasien. Selain itu penting untuk memelihara sarana dan prasarana yang sudah ada agar terjaga kualitasnya.

Sejalan dengan penelitian yang dilakukan oleh Herdanindita, dkk (2020) tentang "Gambaran Perilaku Pemanfaatan VCT (Voluntary Counseling And Testing) pada LSL di LSM SGC (Semarang Gaya Community) Kota Semarang”, hasil penelitian menunjukkan bahwa seluruh informan penelitian yang menggunakan layanan VCT di Puskesmas menyatakan sarana prasarana puskesmas sudah lengkap meliputi ketersediaan ARV, pemeriksaan IMS, media informasi, parkir dan ruang tunggu yang luas, ruangan tidak bersuhu tinggi, gedung layak pakai dan alat pemeriksaan yan bagus. Dengan demikian dapat disimpulkan bahwa dengan keadaan sarana dan prasarana yang baik maka secara tidak langsung membuat pasien ataupun masyarakat merasa nyaman ketika mendapatkan layanan VCT di Puskesmas. Timbulnya rasa nyaman oleh masyarakat ini diharapkan juga agar jumlah kunjungan masyarakat semakin meningkat dalam rangka melakukan pemeriksaan VCT secara sukarela dan pada akhirnya dapat menjadi salah satu upaya dalam program pencegahan dan penularan HIV di masyarakat melalui layanan VCT yang ada di tingkat pelayanan kesehatan dasar (10).

Petugas kesehatan yang memberikan layanan VCT di Puskesmas sudah cukup baik dan lengkap. Berdasarkan hasil penelitian diketahui bahwa di setiap puskesmas terdapat petugas kesehatan yang bertugas sebagai konselor untuk memberikan konseling kepada pasien dan petugas kesehatan yang bertindak sebagai petugas laboratorium untuk melakukan pemeriksaan darah. Para petugas kesehatan memberikan layanan VCT dengan baik, hal ini terlihat ketika memberikan layanan petugas bersikap ramah, sopan satu dan memberikan informasi secara jelas. Faktor konselor menjadi salah satu faktor yang mempengaruhi pelaksanaan VCT seperti hasil penelitian di RSUP Dr. Kariadi Semarang. Hasil penelitian tersebut menunjukkan bahwa faktor yang mempengaruhi pelaksanaan VCT adalah antara lain pengetahuan konselor dan kualitas konselor (11).

Selanjutnya, hasil penelitian oleh Widiyanto pada Wanita Pekerja Seks (WPS) di Lokalisasi Sunan Kuning, Semarang, menunjukkan bahwa lama waktu tunggu dan penggunaan bahasa 
akan mempengaruhi motivasi WPS untuk mau datang ke klinik VCT untuk waktu yang selanjutnya. Penggunaan bahasa yang kurang dimengerti, menggunakan istilahistilah yang tidak familiar bagi WPS akan menurunkan motivasi WPS dan menyebabkan WPS bersikap pasif selama proses konseling, baik pada saat konseling pra-tes maupun konseling post-tes. Akibat yang terjadi mutu konseling menjadi kurang baik dan komunikasi antara konselor dengan klien hanya berjalan satu $\operatorname{arah}(12)$.

Selain itu, pasien merasa mutu pelayanan VCT sudah cukup baik (89\%) dan berdasarkan kompetensi teknis petugas juga sudah baik yaitu sebesar $77 \%$. Hasil penelitian kuantitatif diketahui bahwa Petugas kesehatan mampu menyampaikan informasi tentang HIV dan AIDS dengan lengkap menjelaskan hasil tes laboratorium pasien, memahami keadaan emosional pasien dan menjamin kerahasiaan hasil tes pasien. Hanya saja masih perlunya peningkatan keterampilan petugas dalam menggali informasi pasien karena pasien cenderung tertutup, sehingga komunikasi yang terjadi hanya satu arah. Berdasarkan wawancara, pasien merasa hubungan antara petugas kesehatan dan pasien cukup baik, terutama setelah hasil tes dibacakan, pasien sudah mulai terbuka dan nyaman untuk melakukan konseling, Petugas kesehatan selalu menyapa pasien saat memasuki ruangan, senantiasa tersenyum dan melayani pasien dengan sopan dan ramah. Menurut Pohan (2007) bahwa pasien baru akan merasa puas apabila kinerja layanan kesehatan yang diperolehnya sama atau melebihi harapannya dan sebaliknya, ketidakpuasan atau perasaan kecewa pasien akan muncul apabila kinerja layanan kesehatan yang diperolehnya itu tidak sesuai dengan harapannya (13).

Pasien adalah konsumen akhir layanan kesehatan dan layanan kesehatan bermutu yang diberikan kepada pasien merupakan hasil kerja sama semua petugas kesehatan terkait yang terdapat dalam organisasi layanan kesehatan. Hal tersebut sesuai dengan hasil penelitian yang dilakukan, bahwa hubungan antar petugas kesehatan yang baik, saling berkoordinasi dalam melayani pasien VCT sehingga pasien juga merasa puas dengan pelayanan yang diberikan. Teori Moment Of Truth (MOT) Muninjaya menyatakan bahwa tingkat kenyamanan yang dialami dan bisa dirasakan oleh pelanggan pada setiap interaksi yang muncul antara petugas dan pelanggan. Tingkat kepuasan pelanggan sangat ditentukan oleh mutu proses interaksi langsung antara pasien dengan petugas. Ketiga teori tersebut sesuai dengan hasil penelitian yang diperoleh bahwa hubungan antar petugas kesehatan dengan pasien akan mempengaruhi penilaian pasien terhadap mutu suatu pelayanan kesehatan (14).

Berdasarkan uraian-uraian tersebut dapat dikatakan bahwa petugas kesehatan mempunyai peran yang sangat penting dalam memberikan layanan VCT di Puskesmas. Petugas kesehatan dapat menjadi salah satu indikator kualitas pelayanan yang ada di Puskesmas terutama dalam hal ini berkaitan dengan program penanggulangan HIV/AIDS baik itu berkenaan dengan pemberian informasi tentang penularan dan penyebaran HIV, cara pencegahan, deteksi dini melalui pemeriksaan, pemberian dukungan kepada pasien untuk melakukan pemeriksaan HIV secara sukarela dan melakukan konseling dengan cara yang tepat. Apabila petugas kesehatan dapat melaksanakan tugasnya 
dengan baik maka tentunya akan membuat layanan VCT di Puskesmas semakin baik, hal ini karena memang peran petugas kesehatan masih menjadi faktor pendorong utama yang mempengaruhi pemanfaatan layanan VCT HIV di Puskesmas oleh masyarakat.

Berdasarkan hasil penelitian dan uraianuraian diatas terkait program pencegahan HIV/AIDS melalui layanan Voluntary Testing and Counseling and Testing (VCT) di Puskesmas Kota Jambi diketahui bahwa pelaksanaan VCT telah dilaksanakan dengan baik dan masyarakat juga sudah memanfaatkan layanan VCT tersebut. Dukungan puskesmas dalam upaya pencegahan terhadap penularan HIV/AIDS selain melalui pemberian layanan VCT dapat juga dilakukan dengan program-program lainnya. Salah satu program pencegahan yang dapat dilakukan oleh puskesmas terkait HIV dapat menerapkan model Pencegahan Melalui Transmisi Seksual (PMTS) di Pusat Pelayanan Kesehatan Dasar (Puskesmas). Model PMTS ini bukan hanya menyangkut layanan VCT, akan tetapi terdapat komponen-komponen wajib yang lainnya. Komponen-komponen wajib dalam Model PMTS diantaranya yaitu penyediaan dan distribusi kondom, manajemen infeksi menular seksual (IMS) melalui sirkumsisi, pencegahan berbasis antiretroviral therapy (ART) termasuk perluasan tes HIV, pendidikan kesehatan dan pemberdayaan masyarakat (15). Jadi dengan demikian peran puskesmas dalam upaya mendukung program pencegahan dan penularan HIV/AIDS dapat dilaksanakan secara maksimal dengan melibatkan peran serta masyarakat.

\section{KESIMPULAN DAN SARAN}

Dapat disimpulkan bahwa Pelaksanaan layanan VCT pada umumnya sudah baik. Hal ini didukung oleh wawancara mendalam kepada informan bahwa alur/ SOP pelayanan VCT dari tahap awal hingga akhir sudah baik dan petugas juga telah melaksanakan tahapan testing HIV sesuai dengan standar, yaitu menggunakan Strategi III. Pasien juga mengakui bahwa petugas sangat ramah dan sopan pada saat melakukan konseling. Penilaian informan terhadap tingkat pengetahuan/ pemahaman informasi mengenai VCT dan HIV/ AIDS sudah cukup baik. Hal ini didukung oleh tingkat pendidikan petugas sudah memenuhi standar minimal yaitu Diploma III. Hasil wawancara diketahui bahwa konselor telah memberikan informasi yang jelas tentang VCT dan HIV/AIDS kepada pasien, namun hal ini masih bertolak belakang dengan pernyataan pasien yang masih belum paham terkait dengan tujuan dan manfaat dari layanan VCT ini. Selain itu diketahui pula bahwa petugas telah mengikuti pelatihan terkait VCT dan HIV/AIDS minimal 1 kali.

Saran dalam penelitian ini masih perlu adanya evaluasi berkala terhadap pelaksanaan layanan VCT, peningkatan ketrampilan petugas agar dapat menggali informasi lebih dalam dari pasien, perlu adanya peningkatan pengetahuan melalui pelatihan yang rutin, serta mengupayakan kelengkapan sarana dan prasarana layanan VCT untuk lebih baik lagi.

\section{DAFTAR PUSTAKA}

1. Dinas Kesehatan Kota Jambi. 2019. Laporan Data Penderita HIV/ AIDS di Kota Jambi Bulan Januari-September 2019. Jambi: Dinas Kesehatan Kota Jambi 
2. Kementerian Kesehatan. 2019. Riset Kesehatan Dasar Tahun 2018. Jakarta: Kementerian Kesehatan RI.

3. Kementerian Kesehatan. 2013. Modul Pelatihan Konseling dan Tes Sukarela HIV (Voluntary Counseling dan Testing = VCT) Untuk Konselor HIV Panduan Peserta. Jakarta: Kementerian Kesehatan RI.

4. Budiman, R. A. 2013. Kapita Selekta Kuesioner Pengetahuan dan Sikap dalam Penelitian Kesehatan. Jakarta: Salemba Medika

5. Teklehaimanot, Mekonnen Y., and Dawit B. 2016. Factors Influencing the Uptake of Voluntary HIV Counseling and Testing in Rural Ethiopia: a Cross Sectional study. BMC Public Health.16 (239)

6. Rosida, L., Devi P. 2018. Hubungan Pengetahuan Tentang HIV/AIDS dengan Pemanfaatan Pelayanan VCT di Puskesmas Gedongtengen Yogyakarta. Jurnal Kebidanan, 7 (1), 2018, 23-27

7. Departemen Kesehatan RI. 2006. Pedoman Pelayanan Konseling dan Testing HIV-AIDS secara Sukarela (Voluntary Counseling and Testing). Jakarta: Departemen Kesehatan RI.

8. Notoatmodjo, S. 2010. Ilmu Perilaku Kesehatan. Jakarta: Rineka Cipta

9. Nurhayati. 2016. Faktor - Faktor Yang Berhubungan Dengan Keikutsertaan Ibu Hamil Dalam Pemeriksaan VCT di Puskesmas. Jurnal Human Care, Volume 1 Nomor 3.

10. Herdanindita E., Priyadi N. P., Bagoes W. 2020. Gambaran Perilaku Pemanfaatan VCT (Voluntary
Counseling And Testing) Pada LSL di LSM SGC (Semarang Gaya Community) Kota Semarang. Jurnal Kesehatan Masyarakat FKM UNDIP, Volume 8, Nomor 2, Maret 2020.

11. Dayaningsih, Diana. Studi Fenomenologi Pelaksanaan HIV VCT di RSUP Dr. Kariadi Semarang. Skripsi Program Studi Ilmu Keperawatan Fakultas Kedokteran UNDIP, 2009.

12. Widiyanto, Gunawan S. Faktor-faktor yang Berhubungan dengan Praktik Wanita

13. Pohan, Imbalo S. Jaminan Mutu Layanan Kesehatan. Jakarta: EGC; 2007.

14. Muninjaya, G. A. A. 2012. Manajemen Mutu Pelayanan Kesehatan. Jakarta: EGC

15. Januraga, P.p., Aang S., Vidia D., Ignatius P., M. Suharni., Ignatius H., Ita P., Swasti S., Satiti R.P., \& Eviana H.D. 2016. Model Pencegahan HIV Melalui Transmisi Seksual di Tingkat Pelayanan Primer Puskesmas dan Jejaringnya. Yogyakarta: INSISTPress \& PKMK FK UGM. 